\title{
Kejelasan Sasaran Anggaran, Pengendalian Akuntansi, Sistem Pelaporan dan Akuntabilitas Kinerja Instansi Pemerintah pada Inspektorat Jenderal Kementerian Agama RI
}

\author{
M. Ali Zakiyudin ${ }^{1}$, Suyanto ${ }^{2}$ \\ 1. Universitas Pancasila, Jl. Srengseng Sawah, Jagakarsa, Jakarta Selatan 12640 \\ 2. Sekolah Tinggi Ilmu Ekonomi IPWIJA, Jl. Letda Natsir No.7 Nagrak, Gn. Putri Cibubur - Bogor
}

I N F O A R T I K E L

JEL Classification

$\mathrm{H} 53$

Keywords :

budget goal clarity,

accounting control,

reporting system,

performance accountability

of government agencies.
$A B S T R A C T$

The objective of this research is to verify and explain the affect of budget goal clarity, accounting control, and reporting system toward performance accountability of government agencies. Population in this study are structural officials and staff at Inspectorate General of Ministry of Religion Affair. The sampel used in study are 131 respondents used stratified random sampling. Data analysis was conducted by using multiple regression analysis. The results showed that budget goal clarity, accounting control and reporting system showed affect the performance accountability.

\section{A B S T R A K}

Tujuan dari penelitian ini adalah untuk membuktikan pengaruh kejelasan sasaran anggaran, pengendalian akuntansi, dan sistem pelaporan terhadap akuntabilitas kinerja instansi pemerintah. Populasi dalam penelitian ini adalah pejabat struktural dan staf di Inspektorat Jenderal Departemen Agama. Sampel yang digunakan dalam penelitian ini adalah 131 responden yang dikumpulkan secara stratified random. Analisis data dilakukan dengan menggunakan analisis regresi berganda. Hasil penelitian menunjukkan bahwa kejelasan sasaran anggaran, pengendalian akuntansi, dan sistem pelaporan berpengaruh terhadap akuntabilitas kinerja.

\section{Pendahuluan}

Akuntabilitas telah menjadi prinsip universal dalam penyelenggaraan negara. Di Indonesia, akuntabilitas secara eksplisit diatur dalam Instruksi Presiden Republik Indonesia Nomor 7 Tahun 1999 tentang Akuntabilitas Kinerja Instansi Pemerintah yang menyatakan bahwa dalam rangka lebih meningkatkan pelaksanaan pemerintahan yang lebih berdaya guna, berhasilguna, bersih dan bertanggung jawab, dipandang perlu adanya pelaporan akuntabilitas kinerja instansi pemerintah untuk mengetahui kemampuannya dalam pencapaian visi, misi dan tujuan organisasi. Akuntabilitas kinerja adalah perwujudan kewajiban suatu instansi pemerintah untuk memper-tanggungjawabkan keberhasilan/kegagalan pelaksanaan program dan kegiatan yang telah diamanatkan para pemangku kepentingan dalam rangka mencapai misi organisasi secara terukur dengan sasaran/ target kinerja yang telah ditetapkan melalui laporan kinerja instansi pemerintah yang disusun secara periodik (Pusdiklatwas BPKP, 2011: 2). Seluruh instansi Pemerintah wajib memahami 
lingkup akuntabilitasnya sesuai tugas pokok dan fungsinya masing-masing yang meliputi keberhasilan dan kegagalan pelaksanaan visi dan misi instansi. Sebagai asas umum, akuntabilitas penyelenggaraannegaramenentukanbahwasetiap kegiatan dan hasil akhir kegiatan penyelenggaraan negara harus dapat dipertanggungjawabkan kepada masyarakat sebagai pemegang kedaulatan tertinggi negara. Akuntabilitas merupakan kejelasan fungsi, struktur, sistem, dan pertanggungjawaban organ perusahaan sehingga pengelolaan perusahaan terlaksana secara efektif (Kaihatu, 2006: 3). Dalam menghadapi akuntabilitas, pemerintah perlu memperhatikan beberapa hal, antara lain anggaran, pengendalian akuntansi, efektivitas pelaksanaan anggaran dan sistem pelaporan (Herawaty, 2011: 31). Anggaran publik berisi rencana kegiatan yang dipresentasikan dalam bentuk rencana perolehan pendapatan dan belanja dalam satuan moneter (Ulum MD, 2004: 109), sehingga anggaran tersebut mencerminkan pilihan kebijakan untuk suatu periode yang akan datang. Dalam Undangundang Nomor 17 Tahun 2003 dijelaskan bahwa rencana kerja dan anggaran disusun berdasarkan prestasi kerja yang akan dicapai. Prestasi kerja tersebut tertuang dalam Laporan Akuntabilitas Kinerja Instansi Pemerintah (LAKIP).

Anggaran dibutuhkan oleh sebuah organisasi untuk menerjemahkan keseluruhan strategi kedalam rencana dan tujuanjangka pendek dan jangka panjang. Anggaran merupakan salah satu elemen penting dalam perencanaan agar dapat melakukan pengendalian terhadap pencapaian tujuan organisasi (Ramandei, 2009: 2), sedangkan kejelasan sasaran anggaran merupakan sejauh mana tujuan anggaran ditetapkan secara jelas dan spesifik dengan tujuan agar anggaran tersebut dapat dimengerti oleh orang yang bertanggungjawab atas pencapaian sasaran anggaran tersebut (Suhartono dan Solihin, 2011: 9). Anggaran yang tidak efektif dan tidak berorientasi pada kinerja akan dapat menggagalkan perencanaan yang telah disusun (Bastian, 2001: 275), oleh karena itu kejelasan sasaran anggaran menjadi suatu hal yang sangat relevan dan penting di lingkup pemerintahan karena dampaknya terhadap akuntabilitas pemerintah, sehubungan dengan fungsi pemerintah dalam memberikan pelayanan kepada masyarakat. Salah satu jenis pengendalian manajemen adalah pengendalian keuangan (financial control) dengan memanfaatkan sistem akuntansi, pengendalian tersebut dapat disebut dengan pengendalian akuntansi. Pengendalian akuntansi adalah pengujian terhadap pengendalian yang berhubungan dengan tugas atau transaksi akuntansi (Budiasih, 2002: 119). Pengendalian akuntansi dilakukan untuk melakukan pengujian terhadap sistem perencanaan, sistem pencatatan transaksi dan prosedur monitoring yang didasarkan pada sistem informasi.

Penggunaan sistem pengendalian akuntansi memungkinkan para manajer dapat membuat keputusan-keputusan yang lebih baik, mengontrol operasi-operasi dengan lebih efektif, mampu mengestimasi biaya dan profitabilitas keberhasilan tertentu dan memilih alternatif terbaik dalam setiap kasus dan masalah sehingga dapat meningkatkan kinerja (Nuraini dan Indudewi, 2012: 2). Laporan yang baik yakni laporan yang disusun secara jujur, obyektif, dan transparan (LAN dan BPKP, 2000: 15). Sistem pelaporan biasa dikenal dengan akuntansi pertanggungjawaban. Akuntansi pertanggungjawaban merupakan sistem yang mengukur setiap pusat pertanggungjawaban dan membandingkan hasil-hasil tersebut dengan hasil yang diharapkan atau dianggarkan (Hansen dan Mowen, 2005: 116). Sistem pelaporan yang baik diperlukan agar dapat memantau dan mengendalikan kinerja manajer dalam mengimplementasikan anggaran yang telah ditetapkan. Pemerintah berkewajiban untuk memberikan informasi keuangan dan informasi lainnya yang akan digunakan untuk pengambilan keputusan ekonomi, sosial, dan politik oleh pihak-pihak yang berkepentingan.

Beberapa peneliti telah menguji faktor-faktor diatas yang dianggap dapat mempengaruhi akuntabilitas kinerja instansi pemerintah. Kenis (1979) melakukan pembuktian bahwa kejelasan sasaran anggaran berpengaruh secara positif dan signifikanterhadapkinerja. Sasaran anggaranyang jelas akan memudahkan individu untuk menyusun target-target anggaran. Hasil tersebut sejalan 
dengan penelitian Locke dan Latham (2002) yang mengemukakan bahwa sasaran anggaran yang jelas dan spesifik memiliki pengaruh yang positif terhadap komitmen dan pencapaian sasaran anggaran serta kepuasan karyawan. Anjarwati (2012) mengemukakan bahwa kejelasan sasaran anggaran, pengendalian akuntansi, dan sistem pelaporan berpengaruh secara simultan terhadap akuntabilitas kinerja instansi pemerintah (AKIP) dan secara parsial hanya pengendalian akuntansi yang tidak berpengaruh terhadap AKIP.

Hasil penelitian Darma menunjukkan bahwa kejelasan sasaran anggaran dan sistem pengendalian akuntansi berpengaruh positif signifikan terhadap peningkatan kinerja manajerial, begitu juga dengan hasil penelitian Herawaty (2011) yang menunjukkan bahwa kejelasan sasaran anggaran, pengendalian akuntansi, dan sistem pelaporan juga berpengaruh secara simultan terhadap AKIP, namun secara parsial hanya sistem pelaporan yang berpengaruh terhadap AKIP. Lebih lanjut, Abdullah (2005) dan Nuraini dan Indudewi (2012) mengungkapkan bahwa kejelasan sasaran anggaran, pengendalian akuntansi, dan sistem pelaporan seluruhnya berpengaruh terhadap AKIP. Singkatnya waktu pembahasan anggaran instansi Pemerintah menyulitkan pembuat kebijakan untuk menjalankan fungsi anggaran secara maksimal, sehingga rentan terjadi kesalahan, ketidaktepatan sasaran, dan hanya mengacu pada program tahun sebelumnya yang tidak konstektual dengan kebutuhan mendatang. Pengukuran capaian kinerja dalam (Laporan Akuntabilitas Kinerja Instansi Pemerintah) LAKIP dilakukan dengan metode Performance Gap, yang dilaksanakan dengan membandingkan antara rencana kerja dengan capaian masing-masing kegiatan meliputi input, output, outcome, benefit, dan impact yang dilakukan melalui suatu proses sistematis dan berkesinambungan untuk menilai tingkat keberhasilan maupun kegagalan suatu program dan kegiatan, namun pengukuran indikator benefit dan impact relatif sulit dilaksanakan.

\section{Telaah Teori dan Pengembangan Hipotesis}

Corporate Governance adalah suatu proses dan struktur yang digunakan oleh organ perusahaan (Pemegang Saham/Pemilik Modal, Komisaris/dewan Pengawas dan Direksi) untuk meningkatkan keberhasilan usaha dan akuntabilitas perusahaan guna mewujudkan nilai pemegang saham dalam jangka panjang dengan tetap memperhatikan kepentingan stakeholder lainnya, berlandaskan peraturan perundangundangan dan nilai-nilai etika (Sutedi, 2011:1). Berdasarkan pengertian di atas, Good Corporate Governance secara singkat dapat diartikan sebagai seperangkat sistem yang mengatur dan mengendalikan perusahaan untuk menciptakan nilai tambah (value added) bagi para pemangku kepentingan. Hal ini disebabkan karena Good Corporate Governance dapat mendorong terbentuknya pola kerja manajemen yang bersih, transparan dan profesional. Penerapan Good Corporate Governance di pemerintahan akan menigkatkan kepercayaan publik. Good governance tidak hanya terkait dengan efisiensi, tapi juga berkaitan dengan akuntabilitas berbagai penyelenggaraan kepentingan publik kepada stakeholder-nya. Akuntabilitas publik adalah kewajiban pihak pemegang amanah (agent) untuk memberikan pertanggung-jawaban, menyajikan, melaporkan, dan mengungkapkan segala aktivitas dan kegiatan yang menjadi tanggungjawabnya kepada pihak pemberi amanah (principal) yang memiliki hak dan kewenangan untuk meminta pertanggungjawaban tersebut (Mardiasmo, 2002: 21). Semua unit organisasi, apakah dipilih atau ditunjuk, dikatakan akuntabel ketika mereka mampu menjelaskan dan mempertanggungjawabkan semua tindakan/ kegiatan yang mereka lakukan, dan menerima sanksi untuk tindakan yang tidak layak (tidak dapat dipertanggungjawabkan) (Pusdiklatwas BPKP, 2011: 11), sehingga akuntabilitas kinerja dapat diukur meliputi beberapa tahap, yaitu: perencanaan strategik, pengukuran kinerja, evaluasi kinerja, dan pelaporan/LAKIP. Ellwood (1993) dalam Mardiasmo (2002: 21) menjelaskan bahwa terdapat empat dimensi akuntabilitas yang harus dipenuhi oleh organisasi sektor publik, yaitu: Akuntabilitas Kejujuran dan Akuntabilitas 
Hukum, Akuntabilitas Proses, Akuntabilitas Program, Akuntabilitas Kebijakan.

Anggaran publik berisi rencana kegiatan yang dipresentasikan dalam bentuk rencana perolehan pendapatan dan belanja dalam satuan moneter (Ulum MD, 2004: 109), sehingga anggaran dapat mengestimasikan aktivitas instansi di masa yang akan datang. Kejelasan sasaran anggaran mengacu pada sejauh mana tujuan anggaran dinyatakan secara spesifik dan jelas, dan bisa dimengerti oleh pihak yang bertanggungjawab terhadap pencapaiannya (Kenis, 1979: 709). Sasaran anggaran yang jelas tersebut seharusnya dapat diukur dan dicapai di masa datang, sehingga dapat mendorong pimpinan lebih efektif dan efisien.

Pengendalian keuangan biasa dikenal dengan pengendalian akuntansi. Sistem pengendalian akuntansi internal adalah seperangkat kebijakan dan prosedur yang membatasi dan menjadi pedoman bagi aktivitasaktivitas dalam pemrosesan data keuangan dengan tujuan mencegah atau mendeteksi kesalahan dan tindakan curang (Blocher dkk., 2007: 126). Pengendalian akuntansi dapat memastikan pencatatan sesuai standar yang berlaku pada setiap transaksi keuangan secara akurat dan dapat meminimalisasi adanya kesalahan pencatatan. Prosedur pengendalian akuntansi memiliki tujuan berikut ini (Bastian, 2007: 112): informasi keuangan harus dapat dipercaya sehingga pengelola mendapatkan informasi yang akurat untuk perencanaan program dan pengambilan keputusan lainnya, aktiva dan catatan-catatan organisasi tidak dicuri, disalahgunakan, atau dirusak dengan sengaja, kebijakan-kebijakan yayasan diikuti, dan peraturan-peraturan pemerintah terpenuhi.

Laporan yang digunakan untuk mendukung pembuatan keputusan ekonomi, sosial, politik meliputi informasi yang dapat digunakan (Mardiasmo, 2002), untuk: membandingkan kinerja keuangan akhir dengan yang dianggarkan, menilai kondisi keuangan dan hasil-hasil operasi, membantu menentukan tingkat kepatuhan terhadap peraturan perundangan yang terkait dengan masalah keuangan dan ketentuan

lain, dan membantu dalam mengevaluasi tingkat efisiensi dan efektivitas. Sistem pelaporan merupakan sistem akuntansi yang dipola sesuai dengan tanggung jawab dari setiap bagian/sub bagian dalam organisasi, maka sistem ini didesain untuk menyediakan informasi keuangan secara terpisah, tabel 1.

\section{Metode}

Metode pengambilan data dilaksanakan dengan metode survai menggunakan instrumen kuesioneryang ditujukankepadapejabatstruktural dan staf. Skor yang digunakan dalam penelitian ini menggunakan skala likert dengan gradasi dari nilai yang negatif/terkecil sampai dengan nilai yang positif/terbesar yaitu 1 sampai dengan 5. Sampel yang diambil sebanyak 131 pejabat struktural dan staf dari populasi seabanyak 208 pegawai yang dibagi secara proporsional pada masing-masing unit kerja/wilayah menggunakan Stratified Sampling. Alat analisis dalam pengujian hipotesis menggunakan instrumen regresi linier berganda. Model regresi linier berganda dapat disebut sebagai model yang baik jika model tersebut memenuhi asumsi normalitas data dan terbebas dari asumsi-asumsi klasik statistik, baik itu multikolineritas, autokorelasi, dan heteroskesdastisitas (Nugroho, 2005: 57). Maka tahapan dalam pengujian data terdiri meliputi: uji validitas, uji reliabilitas, uji normalitas, dan uji asumsi klasik yang meliputi uji multikolinieritas dan uji heteroskedastisitas. Persamaan regresi linier berganda (Multiple Regression) yang digunakan adalah sebagai berikut :

$$
\mathrm{Y}=\mathrm{a}+\mathrm{b}_{1} \mathrm{X}_{1}+\mathrm{b}_{2} \mathrm{X}_{2}+\mathrm{b}_{3} \mathrm{X}_{3}+\varepsilon
$$

dalam hal ini:

Y

$\mathrm{X}_{1}$

$\mathrm{X}_{2}$

$\mathrm{X}_{3}$

$\mathrm{a}$

b1, b2, b3

$\varepsilon$
: Akuntabilitas Kinerja Instansi Pemerintah

: Kejelasan Sasaran Anggaran

: Pengendalian Akuntansi

: Sistem Pelaporan

: Intercept (Konstanta)

: Koefisien regresi. 
Tabel 1

Definisi Operasional Variabel

\begin{tabular}{|c|c|c|c|c|}
\hline Variabel & Dimensi & Indikator & Skala & Pustaka \\
\hline $\begin{array}{l}\text { Akuntabilitas Kinerja } \\
\text { Instansi Pemerintah }\end{array}$ & $\begin{array}{l}\text { Akuntabilitas } \\
\text { Kinerja }\end{array}$ & $\begin{array}{l}\text { Akuntabilitas Kejujuran } \\
\text { dan Akuntabilitas Hukum, } \\
\text { Akuntabilitas Proses, } \\
\text { Akuntabilitas Program, } \\
\text { Akuntabilitas Kebijakan }\end{array}$ & Ordinal & $\begin{array}{l}\text { Herawaty (2011), } \\
\text { Ellwood (1993) } \\
\text { dalam Mardiasmo } \\
\text { (2002) }\end{array}$ \\
\hline $\begin{array}{l}\text { Kejelasan Sasaran } \\
\text { Anggaran }\end{array}$ & $\begin{array}{l}\text { Sasaran } \\
\text { Anggaran }\end{array}$ & $\begin{array}{l}\text { Spesifik, Terukur, } \\
\text { Menantang Tapi Realistis, } \\
\text { Berorientasi Pada Hasil } \\
\text { Akhir, Memiliki Batas } \\
\text { Waktu }\end{array}$ & Ordinal & $\begin{array}{l}\text { Kennis (1979), } \\
\text { Nuraini dan } \\
\text { Indudewi (2012) }\end{array}$ \\
\hline Pengendalian Akuntansi & $\begin{array}{l}\text { Prosedur } \\
\text { Pengendalian } \\
\text { Akuntansi }\end{array}$ & $\begin{array}{l}\text { Keandalan Informasi } \\
\text { Keuangan, Aktiva dan } \\
\text { Catatan Organisasi } \\
\text { Tidak Disalahgunakan, } \\
\text { Kebijakan dan Peraturan } \\
\text { Terpenuhi }\end{array}$ & Ordinal & Bastian (2007) \\
\hline Sistem Pelaporan & Informasi & $\begin{array}{l}\text { Membandingkan Kinerja } \\
\text { Keuangan, Menilai } \\
\text { Kondisi Keuangan dan } \\
\text { Hasil-hasil operasi, } \\
\text { Menentukan Tingkat } \\
\text { Kepatuhan, Evaluasi } \\
\text { tingkat efisiensi dan } \\
\text { efektifitas }\end{array}$ & Ordinal & $\begin{array}{l}\text { Mardiasmo (2002), } \\
\text { Anjarwati (2012) }\end{array}$ \\
\hline
\end{tabular}

\section{Hasil Dan Pembahasan}

Semua item pertanyaan dalam variabel penelitian adalah valid karena nilai Corrected Item-Total Correlation lebih besar dari 0,171 (tabel $r$ product-moment) dan reliabel karena semua butir kuesioner variabel menunjukkan nilai Cronbach's Alpha di atas 0.60. Setelah dilakukan uji normalitas data dan asumsi klasik, diketahui bahwa data terdistribusi dengan normal, tidak terjadi multikolinieritas, dan tidak terjadi heteroskedastisitas. Analisis model penelitian dilakukan berdasarkan hasil dari seluruh pengujian statistik baik pengujian parsial maupun pengujian simultan. Dari hasil pengujian pada tabel 2 dan tabel 3 akan dihasilkan kesimpulan penelitian.

Kejelasan sasaran anggaran berpengaruh positif signifikan secara parsial terhadap 
Tabel 2

Uji Signifikan Parsial (T-Test)

Coefficients $^{\mathrm{a}}$

\begin{tabular}{|c|c|c|c|c|c|c|c|c|}
\hline & \multirow[t]{2}{*}{ Model } & \multicolumn{2}{|c|}{$\begin{array}{c}\text { Unstandardized } \\
\text { Coefficients }\end{array}$} & \multirow{2}{*}{$\begin{array}{c}\text { Standardized } \\
\text { Coefficients }\end{array}$} & \multirow[t]{2}{*}{$\mathrm{t}$} & \multirow[t]{2}{*}{ Sig. } & \multicolumn{2}{|c|}{$\begin{array}{c}\text { Collinearity } \\
\text { Statistics } \\
\end{array}$} \\
\hline & & B & Std. Error & & & & Tolerance & VIF \\
\hline \multirow[t]{4}{*}{1} & (Constant) & 4.299 & 1.749 & \multirow{4}{*}{$\begin{array}{l}.152 \\
.393 \\
.335\end{array}$} & 2.458 & .015 & \multirow[b]{2}{*}{.826} & \multirow[b]{2}{*}{1.211} \\
\hline & X1_KSA & .158 & .075 & & 2.094 & .038 & & \\
\hline & $\mathrm{X} 2 \_\mathrm{PA}$ & .486 & .090 & & 5.402 & .000 & .818 & 1.223 \\
\hline & X3_SP & .425 & .096 & & 4.704 & .000 & .851 & 1.175 \\
\hline
\end{tabular}

a. Dependent Variable: Y_AKIP

Tabel 3

Uji Signifikan Simultan (T-Test)

\begin{tabular}{llccccc}
\hline \multicolumn{7}{c}{ ANOVA $^{\text {a }}$} \\
\hline \multirow{2}{*}{ Model } & Sum of Squares & df & Mean Square & F & Sig. \\
\hline 1 & Regression & 258,508 & 3 & 86,169 & 34,716 &, $000^{\text {b }}$ \\
& Residual & 315,232 & 127 & 2,482 & & \\
& Total & 573,740 & 130 & & & \\
\hline
\end{tabular}

a. Dependent Variable: Y_AKIP

b. Predictors: (Constant), X3_SP, X1_KSA, X2_PA

akuntabilitas kinerja instansi pemerintah.

Terbukti berdasarkan hasil perhitungan skor thitung $>$ ttabel yaitu 2,094 > 1,656 dan nilai signifikasi $0,038<$ alpha 0,05 . Hasil ini mendukung penelitian Kennis (1979), Darma (2004), Anjarwati (2012), dan Nuraini dan Indudewi (2012). Pengendalian akuntansi berpengaruh signifikan secara parsial terhadap akuntabilitas kinerja instansi pemerintah. Terbukti berdasarkan hasil perhitungan skor thitung > ttabel yaitu 5,402 > 1,656 dan nilai signifikasi $0,000<$ alpha 0,05. Hasil ini mendukung penelitian Darma (2004) dan Nuraini dan Indudewi (2012). Sistem pelaporan berpengaruh signifikan secara parsial terhadap akuntabilitas kinerja instansi pemerintah. Terbukti berdasarkan hasil perhitungan skor thitung $>$ ttabel yaitu 4,704 $>1,656$ dan nilai signifikasi $0,000<$ alpha 0,05 . Hasil ini mendukung penelitian Anjarwati (2012), Herawaty (2011), dan Nuraini dan Indudewi (2012).

Kejelasan sasaran anggaran, pengendalian akuntansi, dan sistem pelaporan berpengaruh positif signifikan secara simultan terhadap akuntabilitas kinerja instansi pemerintah. Terbukti berdasarkan hasil perhitungan skor Fhitung $>$ nilai Ftabel yaitu 34,716 $>2,68$, dan nilai Sig lebih kecil daripada alpha $(0,05)$ yaitu $0,000<0,05$. Hasil ini mendukung penelitian Herawaty (2011) dan Anjarwati (2012). Kemampuan variabel kejelasan sasaran anggaran, pengendalian akuntansi, dan sistem pelaporan dalam menjelaskan atau memberikan sebagian besar informasi yang dibutuhkan untuk memprediksi variabel akuntabilitas kinerja instansi pemerintah sebesar $43.8 \%$, sedangkan sisanya yaitu $56.2 \%$ dijelaskan oleh variabel lain diluar model.

Persamaan regresi pada hasil penelitian ini dapat dirumuskan sebagai berikut:

$$
\begin{gathered}
\mathrm{Y}=4,299+0,158 \mathrm{X}_{1}+0,486 \mathrm{X}_{2}+0,452 \mathrm{X}_{3}+\varepsilon \\
\text { atau } \\
\mathrm{AKIP}=4,299+0,158 \mathrm{KSA}+0,486 \mathrm{PA}+0,452 \mathrm{SP}+\varepsilon
\end{gathered}
$$

Interpretasi dari persamaan regresi di atas adalah jika variabel-variabel kejelasan sasaran anggaran $\left(\mathrm{X}_{1}\right)$, pengendalian akuntansi $\left(\mathrm{X}_{2}\right)$, 
dan sistem pelaporan $\left(\mathrm{X}_{3}\right)$ dianggap konstan atau sama dengan nol maka nilai akuntabilitas kinerja instansi pemerintah (Y) sebesar 4,299. Jika terjadi penambahan nilai $\mathrm{X}_{1}$ sebesar satu satuan maka nilai akuntabilitas kinerja instansi pemerintah sebesar 0,158 dengan asumsi $\mathrm{X}_{2}$ dan $\mathrm{X}_{3}$ adalah konstan atau sama dengan nol, jika terjadi penambahan nilai pengendalian akuntansi $\left(\mathrm{X}_{2}\right)$ sebesar satu satuan maka nilai akuntabilitas kinerja instansi pemerintah sebesar 0,486 dengan asumsi $\mathrm{X}_{1}$ dan $\mathrm{X}_{3}$ adalah konstan atau sama dengan nol, jika terjadi penambahan nilai sistem pelaporan $\left(\mathrm{X}_{3}\right)$ sebesar satu satuan maka nilai akuntabilitas kinerja instansi pemerintah sebesar 0,452 dengan asumsi $X_{1}$ dan $X_{2}$ adalah konstan atau sama dengan nol.

\section{Kesimpulan, Keterbatasan dan Implikasi Hasil Penelitian}

Berdasarkan hasil pengujian data yang telah dilakukan dengan menggunakan analisis regresi berganda, dapat disusun suatu kesimpulan mengenai hasil uji hipotesis sebagai berikut:

1. Kejelasan sasaran anggaran berpengaruh positif signifikan terhadap akuntabilitas kinerja instansi pemerintah. Sasaran anggaran yang semakin jelas akan meningkatkan

2. akuntabilitas kinerja instansi pemerintah, dalam hal sasaran anggaran yang spesifik, berorientasi pada hasil akhir, memiliki batas waktu

3. Pengendalian akuntansi berpengaruh signifikan terhadap akuntabilitas kinerja instansi pemerintah. Semakin baik prosedur pengendalian akuntansi akan meningkatkan akuntabilitas kinerja instansi pemerintah. jika suatu instansi pemerintah memiliki sistem akuntansi yang handal diharapkan dengan praktik yang sehat, maka informasi akuntansi yang dihasilkan dapat membantu untuk meningkatkan kinerja instansi yang bersangkutan

4. Sistem pelaporan berpengaruh signifikan terhadap akuntabilitas kinerja instansi pemerintah. Sistem pelaporan yang baik akan meningkatkan akuntabilitas kinerja kinerja instansi pemerintah.

5. Kejelasan sasaran anggaran, pengendalian akuntansi, dan sistem pelaporan berpengaruh signifikan secara simultan terhadap akuntabilitas kinerja instansi pemerintah. Peningkatan variabel-variabel independen secara simultan dapat meningkatkan akuntabilitas kinerja pemerintah.

6. Kemampuan variabel kejelasan sasaran anggaran, pengendalian akuntansi, dan sistem pelaporan dalam menjelaskan atau memberikan sebagian besar informasi yang dibutuhkan untuk memprediksi variabel akuntabilitas kinerja instansi pemerintah sebesar $43,8 \%$, sedangkan sisanya yaitu $56,2 \%$ dijelaskan oleh variabel lain diluar model penelitian.

\section{Daftar Pustaka}

Abdullah, Hilmi. 2005. Pengaruh Kejelasan Sasaran Anggaran, Pengendalian Akuntansi, dan Sistem Pelaporan Terhadap Akuntabilitas Kinerja Instansi Pemerintah Daerah. Kompak No. 13, Januari-April 2005 Hal: 3767.

Anjarwati, Mei. 2012. Pengaruh Kejelasan Sasaran Anggaran, Pengendalian Akuntansi, dan Sistem Pelaporan Terhadap Akuntabilitas Kinerja Instansi Pemerintah. Accounting Analysis Journal. Semarang.

Bastian, Indra, 2001. Sistem Akuntansi Sektor Publik. Buku 1. Salemba Empat. Jakarta. 2007. Akuntansi Yayasan dan Lembaga Publik. Penerbit Erlangga. Jakarta. Blocher, Edward J. Chen, Kung H. Cokins, Gary. Lin, Thomas W. 2007. Manajemen Biaya (Buku 1). Edisi 3. Salemba Empat. Jakarta.

Budiasih. 2002. Dampak Pengembangan Teknologi Informasi Terhadap Sistem Informasi Akuntansi. Jurnal Ekonomi \& Bisnis No. 3. Jilid ., Jakarta.

Hansen, Don R. dan Maryanne M. Mowen, 2005. Akuntansi Manajemen, Edisi Tujuh, Buku 2, PT Salemba Empat, Jakarta.

Herawaty, Netty. 2011. Pengaruh Kejelasan Sasaran Anggaran, Pengendalian Akuntansi, 
dan Sistem Pelaporan Terhadap Akuntabilitas Kinerja Instansi Pemerintah Daerah Kota Jambi. Jurnal Penelitian Universitas Jambi Seri Humaniora. Jambi.

Inspektorat Jenderal Kementerian Agama. 2010. Rencana Strategis Inspektorat Jenderal Kementerian Agama Tahun 2010-2014. Jakarta.

Kaihatu, Thomas S. 2006. Good Corporate dan Penerapannya di Indonesia. Jurnal Manajemen dan Kewirausahaan, Vol. 8, No. 1, Jakarta.

Kenis, Izzettin. 1979. Effects of Budgetary Goal Characteristics on Managerial Attitudes and Performance. The Accounting Review. Vol. LIV. No. 4. October. pp. 707-721.

LAN dan BPKP. 2000. Akuntabilitas dan Good Governance. Modul 1. Jakarta.

Mardiasmo. 2002. Akuntansi Sektor Publik. CV. Andi Offset. Yogyakarta.

Nugroho, Bhuono A. 2005. Strategi Jitu Memilih Metode Statistik Penelitian Dengan SPSS. CV. Andi.

Nuraini. Indudewi, D., I. 2012. Pengaruh Kejelasan Sasaran Anggaran, Pengendalian Akuntansi, Dan Sistem Pelaporan Terhadap Akuntabilitas Kinerja Instansi Pemerintah Kabupaten Brebes. Jurnal Solusi Vo. 11 No. 4 Oktober 2012, h. 63-77. Semarang.

Pusdiklatwas BPKP. 2011. Modul Akuntabilitas Instansi Pemerintah. Edisi Keenam (Revisi Kelima). Bogor.

Ramandei, Pilipus. 2009. Pengaruh Karakteristik Sasaran Anggaran Sistem Pengendalian Intern Terhadap Kinerja Aparat Pemerintah Daerah (Studi Empiris pada Satuan Kerja Perangkat Daerah Kota Jayapura). Tesis (tidak dipublikasikan). Program Pascasarjana Universitas Diponegoro. Semarang.

Suhartono, Ehrmann dan Mochammad Solichin, 2006. Pengaruh Kejelasan Sasaran Anggaran Terhadap Senjangan Anggaran Instansi Pemerintah Daerah Dengan Komitmen Organisasi Sebagai Pemoderasi. Simposium Nasional Akuntansi 9. Padang.

Ulum MD, Ihyaul. 2004. Akuntansi Sektor Publik

(Suatu Pengantar). Penerbit Universitas
Muhammadiyah Malang. Malang. 